University of Nebraska - Lincoln

DigitalCommons@University of Nebraska - Lincoln

Faculty Publications from the Center for Plant

Science Innovation

Plant Science Innovation, Center for

June 1997

\title{
Epigenetic Silencing of a Foreign Gene in Nuclear Transformants of Chlamydomonas
}

\author{
Heriberto D. Cerutti \\ University of Nebraska - Lincoln, hcerutti1@unl.edu
}

Anita M. Johnson

Duke University

Nicholas W. Gillham

Duke University

John E. Boynton

Duke University

Follow this and additional works at: https://digitalcommons.unl.edu/plantscifacpub

Part of the Plant Sciences Commons

Cerutti, Heriberto D.; Johnson, Anita M.; Gillham, Nicholas W.; and Boynton, John E., "Epigenetic Silencing of a Foreign Gene in Nuclear Transformants of Chlamydomonas" (1997). Faculty Publications from the Center for Plant Science Innovation. 25.

https://digitalcommons.unl.edu/plantscifacpub/25

This Article is brought to you for free and open access by the Plant Science Innovation, Center for at DigitalCommons@University of Nebraska - Lincoln. It has been accepted for inclusion in Faculty Publications from the Center for Plant Science Innovation by an authorized administrator of DigitalCommons@University of Nebraska Lincoln. 
THE PLANT CELL, Vol 9, Issue 6 (June 1997), pp. 925-945.

Copyright (C) 1997 by American Society of Plant Biologists

\title{
Epigenetic Silencing of a Foreign Gene in Nuclear Transformants of Chlamydomonas
}

\author{
Heriberto Cerutti, Anita M. Johnson, Nicholas W. Gillham, and John E. Boynton
}

Developmental, Cell, and Molecular Biology Group, Departments of Botany and Zoology, Duke University, Durham, North Carolina 27708-1000

\begin{abstract}
The unstable expression of introduced genes poses a serious problem for the application of transgenic technology in plants. In transformants of the unicellular green alga Chlamydomonas reinhardtii, expression of a eubacterial aadA gene, conferring spectinomycin resistance, is transcriptionally suppressed by a reversible epigenetic mechanism(s). Variations in the size and frequency of colonies surviving on different concentrations of spectinomycin as well as the levels of transcriptional activity of the introduced transgene(s) suggest the existence of intermediate expression states in genetically identical cells. Gene silencing does not correlate with methylation of the integrated DNA and does not involve large alterations in its chromatin structure, as revealed by digestion with restriction endonucleases and DNase I. Transgene repression is enhanced by lower temperatures, similar to position effect variegation in Drosophila. By analogy to epigenetic phenomena in several eukaryotes, our results suggest a possible role for (hetero)chromatic chromosomal domains in transcriptional inactivation.
\end{abstract}

This work was supported by National Institutes of Health Grant No. GM-19427 (to J.E.B. and N.W.G.) and a postdoctoral fellowship (project 61-906) from the Jane Coffin Childs Memorial Fund for Medical Research (to H.C.).

The American Society of Plant Biologists does not allow its publications to be archived in an institutional repository. It does, however, provide a free link to full-text content on its own site. Please use the link below to access this article:

$$
\text { LINK = http://www.plantcell.org/cgi/reprint/9/6/925 }
$$

